原著論文

\title{
SD 評点の相関に基づいた被験者間の印象語関係の可視化
}

\author{
小島 輝之*, 山本 康高*, 吉川 大弘*, 古橋 武* \\ *名古屋大学
}

\section{VISUALIZATION OF IMPRESSION WORDS' RELATIONSHIP BETWEEN TWO SUBJECTS BASED ON CORRELATION OF SD DATA}

\author{
Teruyuki Kojima*, Kosuke Yamamoto*, Tomohiro Yoshikawa*, Takeshi Furuhashi* \\ *Nagoya University, Furo-tyo,Chikusa-ku, Nagoya-shi, Aichi 464-8603,Japan
}

\begin{abstract}
The purpose of this study is to visualize the impressions on words between two subjects. We employ Semantic Differential (SD) method that is one of the most popular methods to quantify individual subjectivity. The number of dimensions of each impression word is same with that of objects in SD data. It needs to be reduced to less than three dimensions for visualization. This paper proposes the visualization method which focuses on correlations of SD data between two subjects. The impression words are visualized on three-dimensional space where impression words having high correlation between two subjects' SD data are put close one another. We can investigate and discuss the similarities/differences of impression words between two subjects through this visualized space.
\end{abstract}

Keywords: Visualization, Impression Words, SD method

\section{1.はじめに}

商品開発は，企業内の方針により決定されたコンセプトに 従って行われ，そのコンセプトは言葉により表現される。 し かしながら，言葉に対する印象には個人差があり，この差が コンセプトを伝えるチーフと受け取るデザイナとの意思伝達 の弊害となることもある．本論文の目的は，このような言葉 に対する印象の違いを，視覚的に呈示することである。

個人の対象への印象を定量化する手法の一つに SD 法があ る. SD 法は，ある事柄に対して個人が抱く印象を，相反す る意味の形容詞対（印象語対）を用いて数段階の尺度により 評点し，その尺度の度合いによって対象の意味構造を明らか にしょうとするものである。一般的には, 数個の対象と数個 の印象語対を用意し，1つの対象を見ながら各印象語対の項 目について評点付けを行い，それを全ての対象について繰り 返してもらう。図 1 に, 対象となる 1 つの画像に対する SD 評点の例を示す. 従来研究では, 多人数に対して実施した $\mathrm{SD}$ 法の評点データの平均值に対して因子分析を適用し，印 象語群から潜在的因子を抽出することが多い [1], [2]。し かし，同じ対象であっても抱く印象に個人差が存在するた め，デー夕を平均化することは，それら個人性を消してしま う. それに対し近年, 個人性を考慮した研究が報告され始め ている [3-5]. 柳沢 [3] は，個々人の SD 評点を主成分分 析し，主成分負荷量マップにおいて印象語同士の遠近の違い を論じている，佐々木ら [4] は，個人の色の組み合わせに 対する感性のモデルを同定している。宮崎・萩原 [5] は, ポスター案の感性評価に, 個人の評価を用いたファジィ推論 を導入している。
本論文では，2 名の被験者間における，各印象語に対する $\mathrm{SD}$ 評点の相関值を利用した，印象語の個人性差異の可視化 手法を提案する。同じ印象語に対する印象には個人差が存在 し，また，評点の尺度にも個人差が存在する。そのため，例 えば“かわいい”など同じ印象語に対してそれぞれ比較を行 うことや，各対象への絶対的な点数を用いた比較は，個人性 を考慮したことにはならない，そこで本論文では，SD評点 の相関値に着目する，ここでは，印象語について，各対象に 対する SD 評点の増減が 2 者間で類似していることは, 印象 語や評点そのものは異なっていても，受けた印象が類似して いたことによる主観的評価の表現であったと仮定する，具体 的には，例えば，被験者 $\mathrm{A}$ の印象が「車 $1:$ かわいい，車 2 : かわいい, 車 $3:$ かわいくな」であり, 被験者 B が「車 1 : かっこいい, 車 $2:$ かっこいい, 車 $3:$ かっこ悪い」であっ

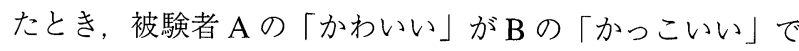
表現されていただけであり，受けた印象そのものは類似して いたと仮定する。

提案手法は，多次元空間中における印象語間の相関值を用 いて距離の基準值を定義し，その距離関係を基に可視空間を 構築する。この基本的な部分について，本手法は多次元尺度 構成法［6-8］の一つとして捉えることができる。ただし， 多次元尺度構成法は, 対称な多次元類似度行列を基に, 各要 素間の類似度関係を保ったまま，それらの相対的位置を多次 元空間内の点として布置する手法である，すなわち，本論文 の目的と照らし合わせれば, 各個人内での印象語間の相対的 位置関係を同定する手法と捉えることができ，個人間で印象 語の捉え方や用い方が異なることを前提に，それらの個人性 差異を可視化することを目的とした提案手法とは，適用方法 や得られる結果が本質的に異なっている. 
本論文では，42 枚の自動車の画像を対象に，自動車に関 倸する 24 個の印象語を用いて，2名の被験者に対して 7 段 階 SD 法による評価を実施する，得られた評点結果に提案手 法を適用し，被験者間の印象語関係を表す可視空間を構築す る，得られた可視化結果に基づき，被験者間の個人性差異に 関する考察結果を報告する，さらに，検証実験を行い，提案 手法の有用性について述べる.

以下， 2 章で提案手法の説明し，3 章において実験結果お よび考察を示す，4章において本手法の検証実験を行い，5 章にてまとめる。

\section{2. 提 案 手 法}

\section{1 前 処 理}

本手法では，印象語についての SD 評点の相関を計算する 必要があるが，ある印象語に対する全ての対象に関して，同 一の評点が付けられている場合, その印象語の評点の分散值 が0になり，相関を計算できなくなる，そこでそのような 印象語については，SD 法において用意する印象語としては 不適切だったとみなし，削除することとする．

\section{2 相関を利用した低次元化射影}

本節では，2名の被験者間における，印象語に対する SD 評点の相関值を利用した印象語の可視化手法について説明す る。提案手法のフローチャートを図 2 に示す.

$\mathrm{SD}$ 法に用いる印象語の数を $p$, 対象の数を $q$ とする. 本 論文では，各印象語が対象の数である $q$ 次元の変数で説明 されていると捉える. 2 名の被験者から SD 法で得られた評 点デー夕を $p \times q$ の行列 $\mathrm{A}, \mathrm{B}$ で表す。また， 3 次元可視空 間における印象語の座標をそれぞれ $p \times 3$ の行列 $\mathrm{X}, \mathrm{Y}$ とす る. 可視空間を線形射影により構築する場合, $\mathrm{X}, \mathrm{Y}$ は $q \times$ 3 の射影行列 T, Uを用いて, $\mathrm{X}=\mathrm{AT}, \mathrm{Y}=\mathrm{BU}$ と表せる. 初めに, $q$ 次元空間中に布置された各印象語を, 3 次元空間 に射影する線形変換行列 $\mathrm{T}$ と U を同定する。ここで提案手 法において線形射影を用いるのは, 誤差の分散が不均一にな るのを防ぎ，解の一意性を保つためである。

提案手法では，2 名の SD 評点の各印象語間に対する相関 関倸に注目し，相関が高い印象語は近く，相関が低い印象語 は遠くに射影される射影行列 T, U を同定し，3 次元可視空 間を構築する。これにより，可視空間上での印象語の遠近が，
$\mathrm{SD}$ 法により，2 名の被験者の主観性デー夕を得る。

$\mathrm{SD}$ データから, 被験者 1 の各印象語 $i$ と被験者 2 の各印 象語 $j$ に対する相関值 $r_{i j}$ を，すべての組み合わせについ て計算する.

被験者間の印象語の関係を可視化するための射影行列 T，Uを，（1）式により同定する

可視空間上における 2 名の印象語の関係から，印象の差 を解析する。

図 2 提案手法のフローチャート

2 名の被験者間の各印象語に対する評点の傾向の類似性や, 同一印象語の相違性を表現し，それらを直感的に把握するこ とが可能となる。（1）式に, 上述の可視空間を実現するため, 本論文で用いる損失関数を示す

$$
\begin{aligned}
& E=\sum_{i}^{p} \sum_{j}^{p}\left\{\alpha_{R} \times\left(1-r_{i j}\right)-\overline{x_{i} y_{j}}\right\}^{2} \\
& \left(x_{i}=\left(\sum_{k=1}^{q} a_{i k} t_{k 1}, \sum_{k=1}^{q} a_{i k} t_{k 2}, \sum_{k=1}^{q} a_{i k} t_{k 3}\right),\right. \\
& y_{j}=\left(\sum_{k=1}^{q} b_{j k} u_{k 1}, \sum_{k=1}^{q} b_{j k} u_{k 2}, \sum_{k=1}^{q} b_{j k} u_{k 3}\right), \\
& \text { ただし, } a_{i k}, b_{j k}, t_{k l} \sim t_{k 3}, u_{k l} \sim u_{k 3} \text { は, それぞれ } \mathbf{A}, \mathbf{B},
\end{aligned}
$$

T, U の要素を表す.）

ここで， $a_{R}$ は，(1）式右辺の第 1 項と第 2 項のスケールを 調整するための定数であり， $r_{i j}$ は， $\mathrm{A} の ~ i$ 番目の印象語の評 点データと $\mathrm{B} の j$ 番目の評点データとの相関值である. また, $\overline{x_{i} y_{j}}$ は, $\mathrm{X} の ~ i$ 番目と $\mathrm{Y} の j$ 番目の印象語間に扮ける, 可視 空間上での評点データのユークリッド距離を表している。(1) 式は, 相関の高い/低い印象語同士（(1-r) 值が小/大）に対し, $\overline{x_{i} y_{j}}$ 值が小さく/大きくなることで誤差 $\mathrm{E} か ゙$ 小さくなる損失関 数である。このように，可視空間上での印象語の遠近が印象 語同士の相関の低高と対応する損失関数であれば, どのよう な関数を用いても本質的な違いはないが $[7]$ ，本論文では， 相関值の違いを等しく扱う線形の損失関数を用いる.

\begin{tabular}{|c|c|c|c|c|c|c|c|c|c|}
\hline 印象語 & 3 & 2 & 1 & 0 & -1 & -2 & -3 & 印象語 & 対象 \\
\hline ボクシー & & & & & & & $\mathrm{v}$ & ボクシーでない & \\
\hline ベイシックな & & & & & & $\mathrm{v}$ & & 特徵的な & \\
\hline やばそうな & & & $\mathrm{v}$ & & & & & 普通の & \\
\hline 安定感のある & & & & & $v$ & & & 不安定な & \\
\hline エキサイティングな & & $\mathrm{v}$ & & & & & & おとなしい & \\
\hline 楽しそう & & $\mathrm{v}$ & & & & & & つまらなさそう & \\
\hline
\end{tabular}

提案手法では，（1）式を最小化する $\mathrm{T}$ と $\mathrm{U}$ を復最適化 により同定する，本論文では， $a_{R}=1.0$ とし， T, U の各要 素 $t_{i j}, \quad u_{i j}$ に $3.0 \sim 3.0$ の範囲で初期值を与えた後, 収束の 
速さと精度を考慮して, 損失関数が減少する方向に各要素を 0.0003 ずつ変化させて最適化を行った.

なお提案手法では, 可視化を前提としており，また可視化 での次元数は大きいほど座標変数の自由度が高くなることで （1）式における誤差 E が減少させやすくなるため, 前述の ように 3 次元可視空間の構築を基本としている. しかし 2 次元平面による可視化は, 結果の把握を容易にするという利

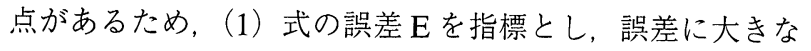
差が見られない場合には，2 次元可視平面を構築する方が解 析をする上で適切である．ただしこの差に対する絶対的な指 標はなく, 結果の把握の容易さと, 情報量の損失に対するト レードオフにより，解析者が決定できる.

\section{3 多次元尺度構成法 $[6-8]$ との相違点}

1.はじめにで述べたように，広義には，本手法は多次元 尺度構成法の一つとして捉えることができる，ただし従来の 多次元尺度構成法は, 対称な多次元類似度行列を扱っている ため, 2 名の被験者の SD 評点から得られる非対称な相関行 列を扱う提案手法とは，適用方法や得られる結果が本質的に 異なっている。

また近年, 非対称性を含むデー夕を扱う多次元尺度構成法 （非対称多次元尺度構成法）が提案されている [9]， [10]. 非対称多次元尺度構成法とは，非対称類似度行列を基に，対 象間の類似度が何らかの距離空間上の距離の関数であると仮 定し, 観測結果としての類似度デー夕の情報をできるかぎり 満たすように，各対象を多次元距離空間内の点として位置づ ける方法である（千野（1997））[9]．すなわち，類似度行 列の非対称性をデー夕の持つ摇らぎとみなし，その摇らぎが できるだけ小さくなるような多次元距離空間上での点を同定 する手法である，また，前述の “何らかの距離空間” とは， ユークリッド距離ではなく，例えば 2 点 $\mathbf{A}, \mathbf{B} に つ い て ， \mathbf{A}$ $\rightarrow \mathbf{B}$ と $\mathbf{B} \rightarrow \mathbf{A}$ の距離が異なる距離空間であり, 得られる可 視空間の解釈方法は特殊なものとなる. 類似度行列の非対称 性の原因は, 対象間で認知する側と認知される側が存在する ためとされており, 非対称多次元尺度構成法を用いることで 認知する側から見たときの距離と認知される側から見た時の 距離を視覚的に捉えることが可能となる．ただし，1つの対 象に対応する空間布置は 1 つという立場は対称類似度行列 を扱う多次元尺度構成法と同様であり，提案手法のように， 非対称性の関係となる対象のラベルは同じでもその性質は異 なるとは捉えていないため，2 者間の印象の差を見るために 適した手法とはいえない. 特にこの点において, 個人性差異 を可視化し，視覚的にそれらを把握することを目的とした提 案手法とは大きく異なっている。

\section{3. 実験結果及び考察}

\section{1 実 験 方 法}

自動車のデザインに対する印象の個人性の差異の明示化を 目的とし, 自動車の画像を 24 種類, 印象語を 42 対用意し,
7 段階の SD 法により 2 名の被験者に評価させた。被験者は いずれも 20 代の大学院生である. なお本手法は, これらバッ クグランドに依存せず適用することが可能であり，異なる バックグランドの被験者間であっても，得られる可視空間の 信頼性は同じである。また本実験で用いた印象語は，SD法 で一般的に用いられているもの,「車, デザイン」をキーワー ドとしたインターネット検索, および [3]，［11］に掲載さ れている語句の中から，車の評価として関係のある語句を抽 出した。この中には，「やばそうな」といった抽象概念の強 い表現や，「乗り降りしにくい」などの機能に関わる語が存 在するが, 抽象性を持つ印象語と, 機能や具体性を持つ印象 語との関連や印象差を把握できることも, 解析の上では有益 だと考えられる．今回はこの 2 名の被験者間における印象 語の個人性差異の可視化を目的とし, 得られた SD 評点結果 に対して提案手法を適用した。用いた印象語を表 1 に，自 動車の画像を図 3 にそれぞれ示す。

なお本実験において, 可視化次元数が 1 次元, 2 次元, 3 次元の場合の本手法による誤差 E（(1）式）を比較したとこ ろ，それぞれ約 330 , 約 60, 約 30 であった．また, 1 から 相関行列の各要素值をひいた非類似度行列と, 可視空間上で の距離行列との相関値は, それぞれ 1 次元の場合が $0.37,2$ 次元が $0.87,3$ 次元が 0.93 であった. そこで本実験では, 相関值 0.8 以上を指標とし, 2 次元平面への印象語の付置を 行う.なお本実験では, 相関值 0.8 を可視化次元数の決定の 指標としたが, 2.2 で述べた通り，この指標や次元数は解析 者の目的に応じて決定できる.

\section{2 可 視 化 結 果}

提案手法を適用した結果，得られた 2 次元平面を図 4 に 示す．提案手法では，相対的な距離関係のみを考慮して射影 を行っているため, 軸や座標値には特別な意味を持たせてい ない，そこでここでは，相対的な距離関係に焦点を当てて議 論する.

図 4（a）の全体図を見ると，2者間で印象語が混ざり合っ ておらず, 被験者 1 の印象語が内側に, 被験者 2 の印象語 が外側に固まっていることがわかる，このことから，各々が 独自の印象を持っており，この 2 者間では同一の印象を共 有できる印象語が少ない，いわば互いに意思疎通の図りづら い被験者だったと推測される，ただし，左上にベイシックさ を連想させる印象語群，右下にスポーティさを連想させる印 象語群が集まっているという点では共通しており，大まかな 印象構造は互いに類似しているといえる。

またその中でも，図4（b）における「実用性が高い」は， 2 者間で同じ印象語が比較的近い位置に配置されており，2 者で類似した印象表現であったと考えられる。この他に例え ば図 4 （b）から，「1：オーソドックス・実用性が高い・大 人の落ちついた感じ・ベイシックな・ゆったりしている・安 定感のある -2 : 実用性が高い」は，2 者間で類似した印象を 共有可能にする印象語群であり, 被験者 2 にとっての実用 的な自動車のイメージは, 被験者 1 のこれらの印象語郡の 
イメージに近いものであると考えられる。また図4(c)から，

$「 1$ ：自然な・浮き浮きした・親しみやすい・知性を感じさ せる-2：スタイリッシュ」についても同様に類似した印象 を表現する言葉であるが，印象語の性質が異なっていること がわかる。被験者 1 が䨌囲気のポジティブさを感じた自動 車は，被験者 2 にっては自動車の形態のポジティブさ感 じる場合があることを示唆している。また図 4 (d) より,「や ばそうな」が，共にもう一方の「スポーティ・エキサイティ ングな」と近い位置にあることは興味深い結果である。抽象 概念の強い印象語ではあるが，2 者間で抱いた印象は比較的 類似していたことが推測される。

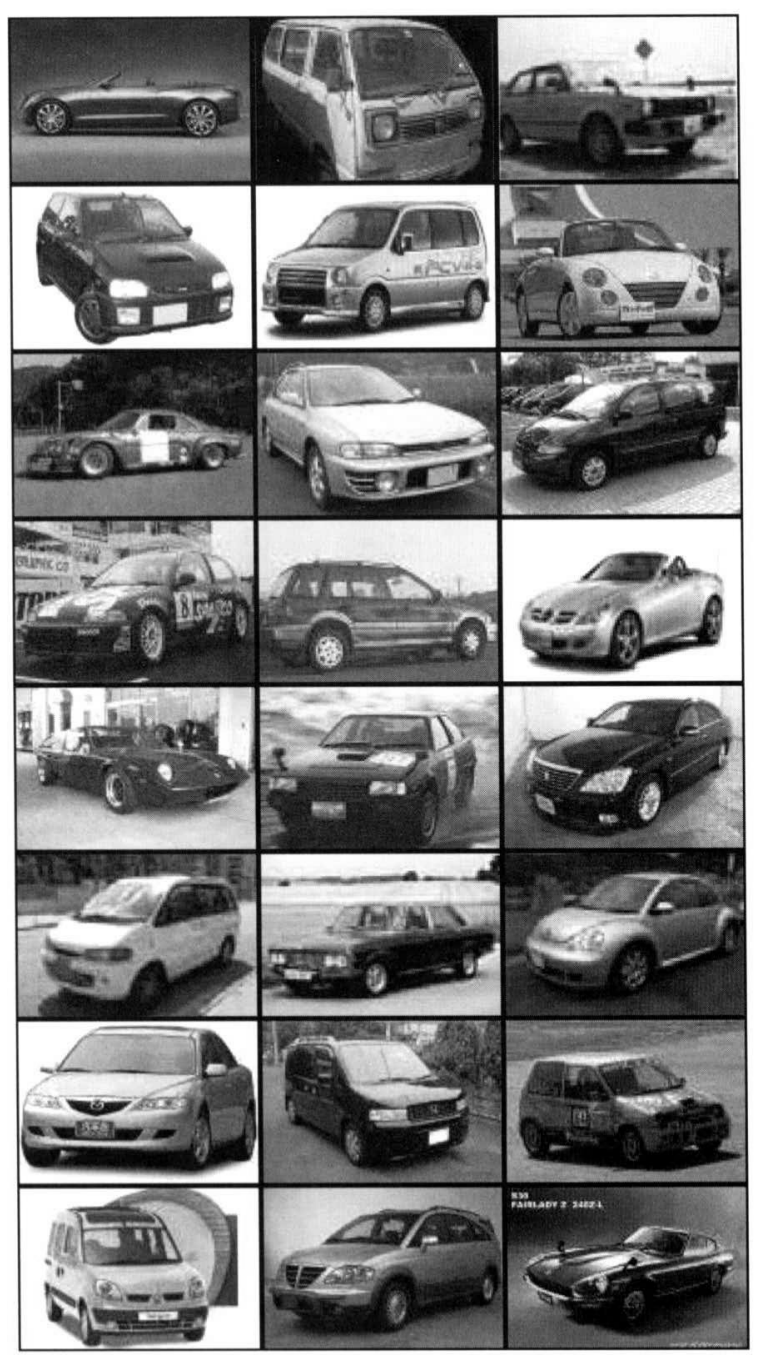

図 3 SD 法で用いた自動車の画像
表 1 SD 法で用いた印象語

\begin{tabular}{|c|c|}
\hline ボクシー & ボクシーでない \\
\hline ベイシックな & 特徵的な \\
\hline やばそうな & 普通の \\
\hline コンパクト & 広範囲にわたる \\
\hline タイヤが大きい & タイヤが小さい \\
\hline 床が高い & 床が低い \\
\hline 乗り降りしくい & 乗り降りしやすい \\
\hline スポーティ & スポーティでない \\
\hline 実用性が高い & 実用性が低い \\
\hline 先進的な感じ & 古めかしい \\
\hline シャープな & 鈍い \\
\hline おしやれな & 無粋·野暮 \\
\hline 知性を感じさせる & 知性を感じない \\
\hline オーソドックス & 異端の \\
\hline にぎやかな & 静かな \\
\hline 親しみやすい & 親しみにくい \\
\hline 開放的な & 閉鎖的な \\
\hline 浮き浮きした & 嘆かわしい \\
\hline 明るい & 暗い \\
\hline さわやかな & 気持ち悪い \\
\hline 大人の落ちついた感じ & 子供つぽくて騒がしい \\
\hline ゆったりしている & こせこせしている \\
\hline 自然な & 人工的. 不自然 \\
\hline 派手な & 地味 \\
\hline 華やかな & 目立たない \\
\hline 斬新な & 陳腐な \\
\hline 複雑な & 単純な \\
\hline 高級感がある & チープな感じ \\
\hline 格調がある & 品格ない \\
\hline モダン調 & クラシックな \\
\hline 都会的 & 田舎的 \\
\hline 豪華そう & 簡素·貧弱そう \\
\hline 渋い & 渋くない \\
\hline 素朴な & 素朴でない \\
\hline かわいい & かわいくない \\
\hline カッコイイ & ださい \\
\hline スタイリッシュ & だらしない \\
\hline 魅力的な & 質素な·平凡な \\
\hline アクティブ & 不活発な \\
\hline 安定感のある & 不安定な \\
\hline エキサイティングな & おとなしい \\
\hline 楽しそう & つまらなさそう \\
\hline
\end{tabular}




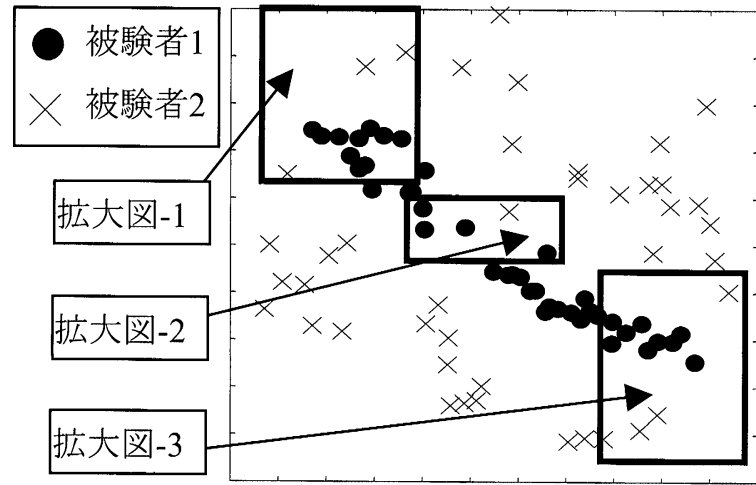

(a) 全体図

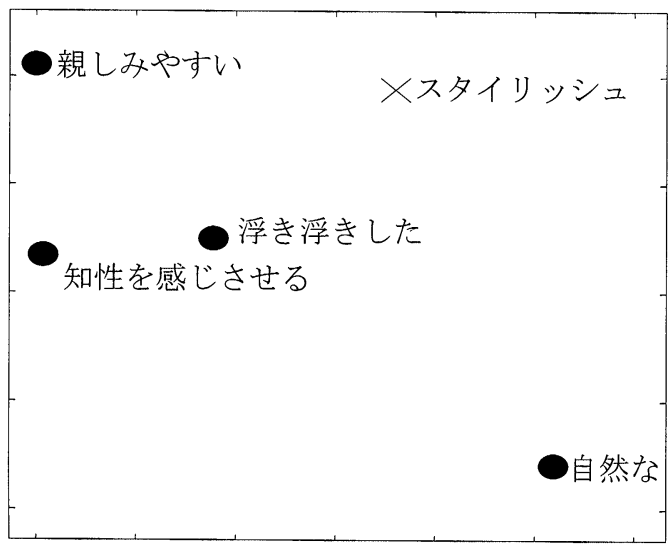

(c) 拡大図-2

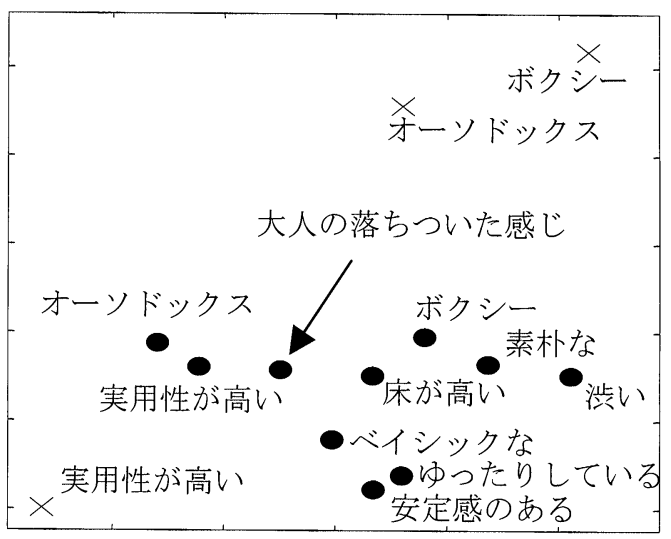

(b) 拡大図-1

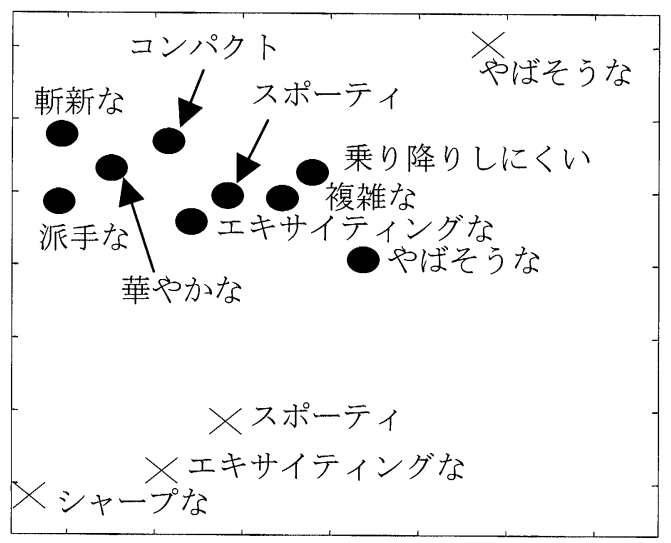

(d) 拡大図-3

図 4 得られた可視化結果

\section{4. 検 証 実 験}

本章では，提案手法に対する検証として，実験デー夕の信 頼性および得られた可視化結果の有用性を論じる。

\section{1 実 験 方 法}

図 5 および表 2 に示す自動車画像 10 種類，印象語を 20 対 用意し，7段階の SD 法により5名の被験者に評価させた． 被験者はいずれも 20 代の大学生・大学院生である。本実験で は，背景が白地の自動車画像を対象とし，印象語については 表 1 の 42 対の印象語の中から抽象性を持つものを選択した。

初めに，実験デー夕そのものの信頼性に対する検証とし て，5名の被験者に，同じ対象群，印象語群を用いて日を分 けて 2 回のSD 法を適用した。その際には，1 回目と 2 回目 で対象と印象語それぞれの提示順序を変え，評点のゆらぎに ついて確認を行った.

次に，提案手法により得られた可視化結果の有用性に対す る検証として，上記 2 回の実験により得られた SD 評点のう ち, 1 回目の SD 評点を分析用デー夕，2 回目の SD 評点を検 証用データとし，分析用デー夕の可視化結果に対する考察の 妥当性を，検証用データの可視化結果と合わせて検討した.
表 2 印象語（検証実験）

\begin{tabular}{|c|c|}
\hline エキサイティングな & おとなしい \\
\hline カッコイイ & ださい \\
\hline かわいい & ぶさいくな \\
\hline コンパクト & 広範囲にわたる \\
\hline さわやかな & うっとうしい \\
\hline シャープな & 丸い \\
\hline スポーティ & スポーティでない \\
\hline ベイシックな & 特徵的な \\
\hline ボクシー & ボクシーでない \\
\hline 華やかな & 目立たない \\
\hline 楽しそう & つまらなさそう \\
\hline 高級感がある & チープな感じ \\
\hline 実用性が高い & 実用性が低い \\
\hline 親しみやすい & 親しみにくい \\
\hline 先進的な感じ & 古めかしい \\
\hline 素朴な & 複雑な \\
\hline 大人の落ちついた感じ & 子供っぽくて騒がしい \\
\hline 知性を感じさせる & 知性を感じない \\
\hline 都会的 & 田舎的 \\
\hline 派手な & 地味 \\
\hline
\end{tabular}



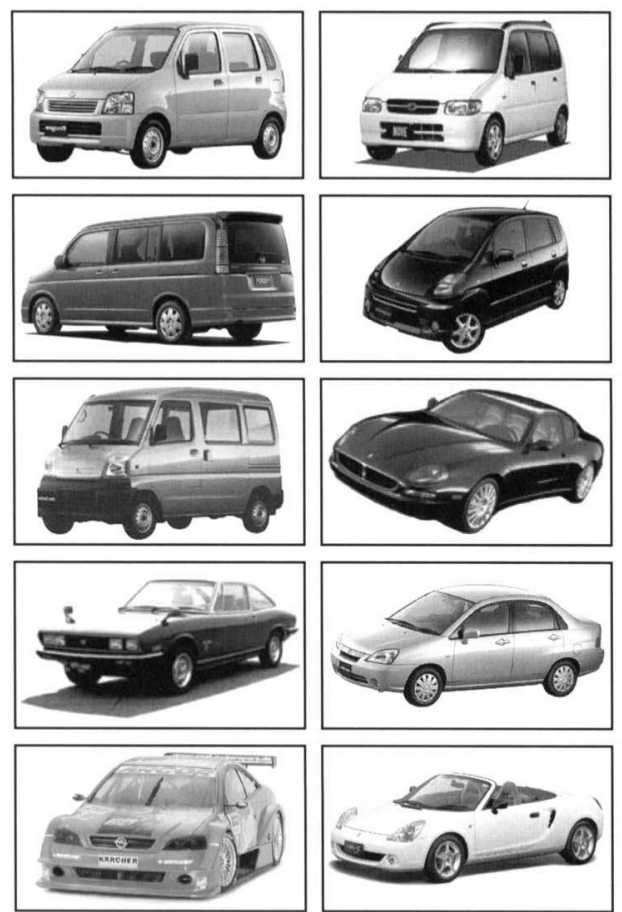

図 5 自動車画像（検証実験）

\section{2 実験結果及び考察}

\subsection{1 実験データの信頼性}

ここでは, 各被験者の 1 回目と 2 回目のSD法に抢ける評 点データそのものの相関值を，得られたデータの信頼性に対 する指標とする.4.1で述べた方法により実験を行った結果， 被験者 1 ～ 5 の評点デー夕の相関值は， $(0.82 ， 0.82,0.84$, $0.81 ， 0.84$ ）となり， 5 人の平均が 0.83 となった。各被験 者とも 1 回目と 2 回目の評点の相関值が高いことから, 細 かな評点の変化はあるものの, 数日の時間間隔, 対象や印象 語の提示順序の影響によって, 各被験者の評点基準は大筋で は変化していないと考えら机る。

\subsection{2 可視化結果の有用性}

ここでは，得られた可視化結果の妥当性について検証す る. 5 名の中から無作為に選択した 2 名の被験者の分析用デー 夕, 検証用データに対して, 提案手法により得られた 2 次 元平面をそれぞれ図6, 四7 に示す。な扮本実験においても, 1 次元, 2 次元, 3 次元可視化での誤差 E ((1) 式) は, そ れぞれ約 170 , 約 12, 約 8, 非類似度行列と距離行列との 相関值はそれぞれ $0.16,0.94,0.92$ であったため, 2 次元 平面への印象語の付置を行った３章で示した誤差の值と大 きく異なっているが, これらは用いた印象語の数の違いによ るものである，印象語の数が増えれば，類似度行列における 要素数, すなわち印象語間の類似関係の数が増え, それらの 関係を保持することが困難となっていく，結果として印象語 の数が多いほど, 䛊差 $\mathrm{E}$ の值は大きくなるが, 相関值は印 象語の数に依存しない.

初めに図6について考察をする。全体㘠をみると, 眓6(a) 下部において、「ボクシー・実用性が高い・素朴な」といっ
た機能性や普通さを連想させる印象語群が配置され，右部に 「コンパクト・かわいい・親しみやすい」といった単純さや 小ささに関連する印象語群が配置されている，また，左上部 (図6（b））には「エキサイティングな・シャープ・派手な」 といったデザインの奇抜さを連想させる印象語群が配置され る結果となった。ささらに全体の傾向として，多くの同じ印象 語が近くに配置されやすい傾向があることから，2 者間で車 に関する印象，およびそれらに対して用いる印象語はおおむ 水類似して㧍り, 意思疎通の図りやすい被験者であったと考 えられる，その中でも「ベイシックな」や「コンパクト」な どは比較的離れた位置に配置されており，2 者間で標準的な 車の基準やコンパクトと感じる車の規模が若干ずれているこ とが推測される。

次に, 図7の結果を図6 と比較して考察する。「さわやか な」や「大人の落ちついた感じ」など, 一部で距離関係が図 6 と異なっている印象語も存在するが, 眓 6 と同様, 全体的 には同一印象語の距離関係は近い傾向にあることがわかる. また「コンパクト」は若干近くなったが、「ベイシックな」 などについても，他の印象語と比較して離れた位置となって いる，全体を通じて，扮抄む权分析デー夕の結果に対する考 察が未知デー夕にもあてはまる結果となった。

\section{5. まとめ}

本論文では，2 者間で同じ印象語に対して抱く印象の同異 や，同じ印象を与える印象語の個人的な差異を明示化するこ とを目的とし，2名の SD 評価データの相関係数に着目した 印象語間の関倸の可視化手法を提案した，提案手法により， 2 名の印象語に対する個人性差異を可視化し，印象語間の関 係に対して，他者と知識を共有できる材料を提供可能である ことを示した，本手法により，2 者間で意思疎通の行い易い 印象語の発見や，同一の印象を表現するための印象語の対応 付けなどが期待できる.

今後の課題として, 2 名の被験者が着目していた対象の特 徵量の明示化が挙げられる.SD法を行うときに対象画像の どの部分に着目し評価したかによって印象が変わることが考 えられる、このことに関する提案手法を通した議論の可能性 や，その検証方法などについても考察していきたい．また本 論文では，個人間の印象差異について検討を行ったが，何ら かの基準により層別されたグループの平均データを用いて, グループ間の印象差異を把握する解析を行っていくことも, 今後の課題として挙げられる。

\section{謝 辞}

本研究の一部は, 21 世紀 COE「計算科学フロンティア」 掞よび文部科学省科学研究費（基盤研究 @(2) No.16500126） の補助を得て遂行された。 


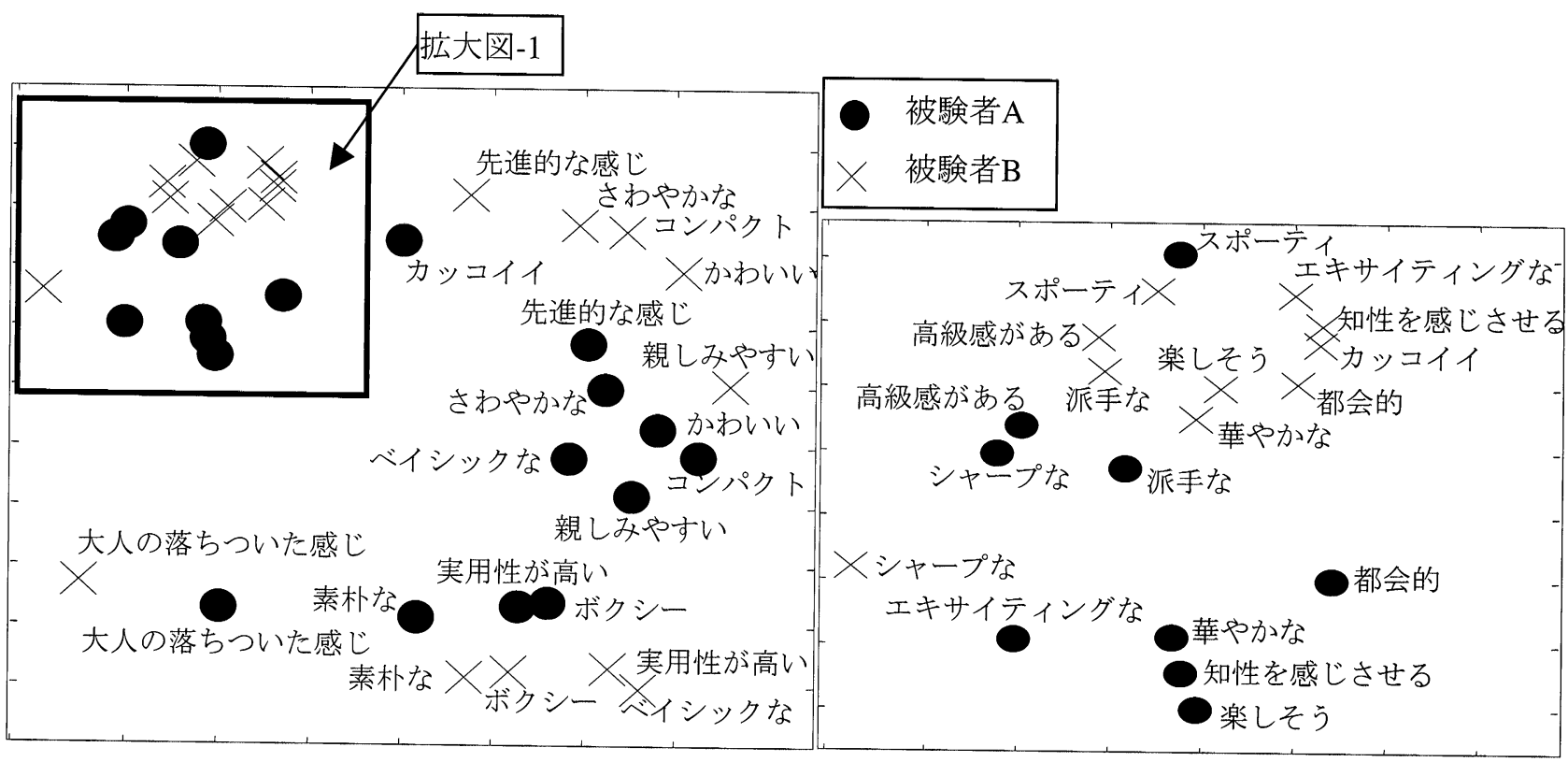
(a) 全体図
(b) 拡大図-1

図 6 可視化結果（分析用データ）

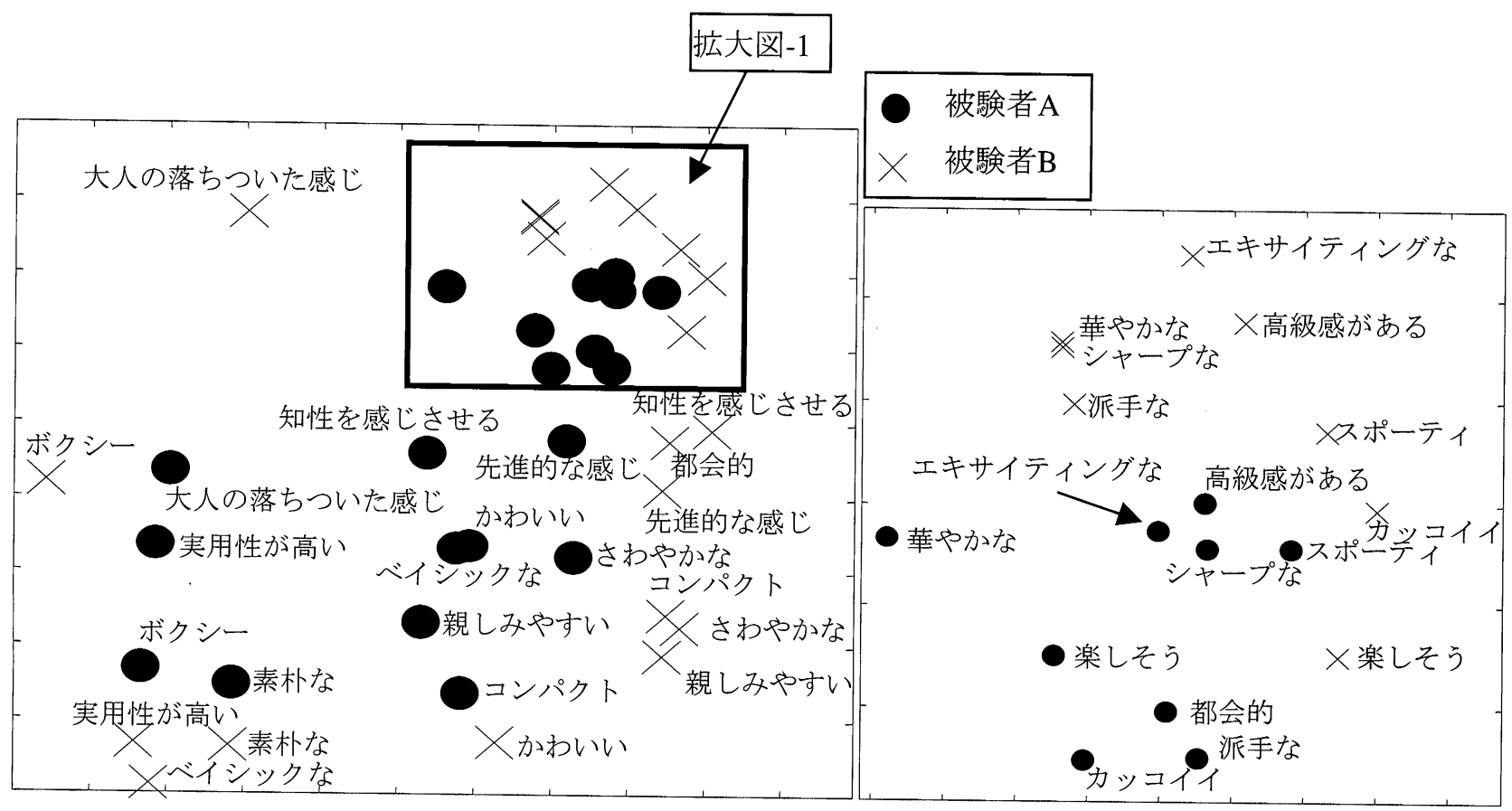

(a) 全体図

(b) 拡大図-1

図 7 可視化結果（検証用データ） 


\section{参考文 献}

［1］石坂俊博, 川路茂保, 田島年浩, 荒尾真樹：ペットロボッ トの動作による印象の評価, 第 3 回日本感性工学会予稿 集. 124. 2001

[2] 南谷峰子, 佐藤和明, 林浩之, 中森義輝, 野村淳二, 今村 佳世, 長町三生：製品の主観評価に対するファジィモデリ ング, 第 11 回ファジィシステムシンポジウム, 279-282, 1995

［3］柳澤秀吉：個人により異なる評価特性に着目した感性要求 の具体化支援設計手法の開発，東京都立科学技術大学博士 学位論文, 2004

４4］佐々木麻里, 本田ゆき江, 松村幸恵, 寒川聖文, 井田勝, 加藤俊一：色の組み合わせと配置を考慮したカラーコー ディネート事例の分析とモデル化ーインテリア, ファッ ションへの応用一, 第 6 回日本感性工学会予稿集, 331 , 2004

[5]宮崎隆之, 荻原将文: 感性を反映できるポスター作成支援 システム, 情報処理学会論文誌, 38, 10, 1928-1936, 1997

[6] 岡太涁訓, 今泉忠 : パソコン多次元尺度構成法, 共立出版 株式会社, 1994

[7] 高根芳雄：人間科学の統計学 1-多次元尺度法一, 朝倉書 店, 1980

［8］斉藤克幸：多次元尺度法, 朝倉書店, 1980

[9] 千野直仁：非対称多次元尺度構成法一行動科学における多 変量デー夕解析一, 現代数学社, 1997

[10] 千野直仁, 岡太涁訓: 非対称多次元尺度構成法とその周辺, 行動計量学, 23, 130-152, 1996

[11] 張育銘, 森典彦：ニューラルネットで統合するファジイ逆 推論を用いた自動車デザイン支援システム、日本ファジィ 学会誌, 5, 5, 1233-1245, 1993

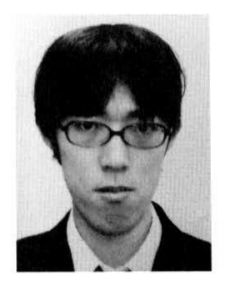

に従事.

\section{小島 輝之}

2005 年 3 月名古屋大学 工学部 電気電子情報 工学科卒業. 同年 3 月. 名古屋大学大学院 工学研究科 電子情報システム専攻 博士前期 課程に進学、現在に至る．多次元デー夕の可 視化技術および感性デー夕解析に関する研究

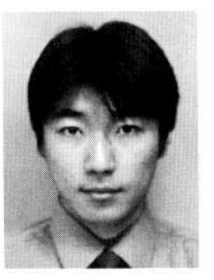

\section{山本 康高}

2003 年 3 月三重大学大学院 工学研究科 電気 電子工学専攻 博士前期課程修了. 同年 4 月. 博士後期課程に進学, 2004 年 4 月より名古 屋大学大学院工学研究科計算理工学専攻に 転入学. 現在に至る. 多次元データの可視化 技術掞よび感性デー夕解析に関する研究に従事

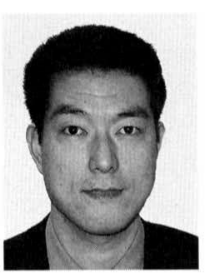

\section{吉川 大弘}

1997 年名古屋大学大学院博士後期課程修 了. 同年カリフォルニア大学バークレー校ソ フトコンピューティング研究所客員研究員.

1998 年三重大学工学部電気電子工学科助 手. 2005 年名古屋大学工学研究科 COE 特任 助教授. 現在に至る。主としてソフトコンピューティングとそ の応用に関する研究に従事. 博士 (工学).

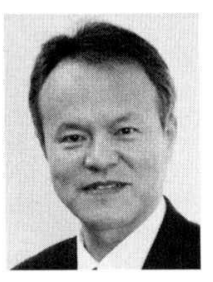

\section{古橋 武}

1985 年 3 月名古屋大学大学院博士課程修了, 1990 年 12 月より同大工学部助教授, 2001 年 1 月より三重大学 情報工学科教授, 2004

年 4 月より名古屋大学大学院工学研究科教 授. 現在に至る. 工学博士. 94 年日本ファジィ 学会論文賞受賞、主として、ソフトコンピューティングに関す る研究に従事. 